Pereszlényi-Pintér, Mártha. "Fischer, Linda. 2014. The Memory Book - One Woman's Self-Discovery in the Mist of the Austro-Hungarian Monarchy. New York: Minted Prose. 326 pp." Hungarian Cultural Studies. e-Journal of the American Hungarian Educators Association, Volume 10 (2017) DOI: 10.5195/ahea.2017.307

\title{
Fischer, Linda. 2014. The Memory Book-One Woman's Self- Discovery in the Mist of the Austro-Hungarian Monarchy. New York: Minted Prose. 326 pp.
}

\section{Reviewed by Mártha Pereszlényi-Pintér*, John Carroll University}

In 2005, while on a short vacation to Budapest, Linda Fischer chanced upon a small leather-bound book in an antiques shop. It turned out to be a "memory book," a keepsake album and a common tradition kept by Central-European girls at the turn of the twentieth century (as probably elsewhere and throughout time), in which they recorded and perpetuated special events; such books may also have included entries by the main author's friends and family members. Upon opening the book, Fischer found it filled with watercolors, drawings, messages, evergreen truisms, and warm time-period aphorisms written by and to the book's owner, Amálka (Amália), including mention of places that Amálka had visited and which few Americans have ever heard of, much less seen. Fischer found the drawing- and writing-filled book not just captivating but compelling, albeit she did not understand the Hungarian language in which it was written. She therefore began a quest to find out who this Amálka was and what her life was like. Obviously Fischer first had to find a translator to decipher the memory book's old-fashioned handwriting and its sometimes formal language, and this mission was soon carried out by Ivan Sanders. At that point, driven by curiosity and concern, Fischer no less than undertook a several-year long journey into the heart of old East-Central Europe and deep into centuries of its art, history, and wars.

Fischer's book is thus a non-fiction account of her own travels through the former Austro-Hungarian Monarchy, including extensive historical details and selected fragments from the writings of nineteenth- and twentieth-century travelers to the region, most of which is nowadays divided into several East-Central European states. Fischer paid much attention to the historical background of Amálka's memory book and accordingly she presents helpful historical sources, dating back to 1830, in the book's twenty-eight pages long bibliography. Thus, The Memory Book draws its reader into Fischer's journey of discovery, including self-discovery, while beautifully introducing and elucidating the history and culture of the late AustroHungarian Empire in which the original author of the memory book, Amálka, had once lived.

Following a Preface, the book is divided into four main parts of six to eleven chapters each. In addition, three addendums consist of the following: the author's research at the Morgan collection of illuminated manuscripts once held in the King Matthias Royal Library at Buda; English translations of poetry snippets by Hungarian literary icons (Mihály Babits, Károly Kisfaludy, Mihály Vörösmarty, János Arany, Ferenc Kazinczy, Sándor Petőfi), and of a few

*mpereszlenyi@jcu.edu

$($ (c) $)$ EY

ULIS D-Sente
New articles in this journal are licensed under a Creative Commons Attribution 4.0 International License.

This journal is published by the University Library System of the University of Pittsburgh as part of its D-Scribe Digital Publishing Program and is cosponsored by the University of Pittsburgh Press 
Pereszlényi-Pintér, Mártha. "Fischer, Linda. 2014. The Memory Book - One Woman's Self-Discovery in the Mist of the Austro-Hungarian Monarchy. New York: Minted Prose. 326 pp." Hungarian Cultural Studies. e-Journal of the American Hungarian Educators Association, Volume 10 (2017) DOI: 10.5195/ahea.2017.307

lesser-known authors selected by Fischer; and a recipe for krémes, a pastry often known in English as a napoleon. The book also includes maps, illustrations, photos, portraits of famous historical or literary figures, and scraps of information for readers who might know very little about the region and its history, or as an aide-mémoire for those who know more. In these texts Fischer supplies necessary historical, geopolitical, literary and cultural information, and all these texts are set at the ends of chapters in a different typeface and against a shaded background to avoid deceleration from the book's main narrative. Fischer's passion for and knowledge of the history, genealogy, culture, literature, folklore, cuisine and people of the region is so palpable that one could assert that she turns all these into a magical and mystical atmosphere. This may account for the near-decade it took her to complete this project, but the result is a book that garners a treasure and much pleasure for people who enjoy history, travel and memoirs, and for those wishing to know more about Hungary. It is also a compelling read for lovers of genealogy and nostalgic artifacts.

Fischer's The Memory Book offers a welcome modern annotation to Amálka's memory book; yet this is not your average memoir or travelogue. Instead, Fischer's work amounts to a near-obsessive quest and a personal exploration of Austria-Hungary and the countries into which large parts of it were divided following World War I and the 1920 Trianon Peace Treaty. Seen from the vantage point of a century later, Hungary's unfortunate involvement in two world wars and its heavy penalty for this involvement left the country and its people with open wounds, which Fischer also explores just as she does, though more succinctly, with the Hungarian nation's entire eleven-hundred years of existence.

While Fischer's book presents a parallel narrative between Fischer's expeditionjourney and Amálka's coming of age, it is, first and foremost, Fischer's story, her memoir of an American woman lured by the mysterious manuscript of a foreign young girl living a hundred years or more before her own time. Thus the book delineates Fischer's own voyage of selfdiscovery transcending continents, centuries and cultures. When Amálka died, her intimate keepsake may have been passed on to a relative, and when that person died, the precious manuscript ended up at a flea market to be purchased by an antique shop owner. By pure serendipity, it fell into the hands of this American woman who was attracted by its genre and charm to the extent that she started her own journey in the footsteps and landscape of the memory book's long dead author.

Interestingly, both Fischer and her husband Phil, who accompanied her on her multiple voyages of discovery, are native New Yorkers and have no Hungarian roots: she has Italian roots and he Russian. While their story centers on their visits to Budapest and other towns and cities in Hungary, they also voyage through other places in the former Austro-Hungarian Empire such as Vienna, Prague and Krakow, where World War II and its aftermath still cast their gloomy shadow. For example, in Poland, they visit the site of industrialist Oscar Schindler's Emalia Factory of Enameled Vessels, presently a modern museum. During WW II, the factory also manufactured munitions for the Nazi-German war effort but Schindler saved many of his Jewish workers from death in the Nazi camps. In Hungary the Fischers visit Pécs, where they are inspired by the artworks whose reproductions they first saw in Amálka's memory book; and in Szolnok, with its world-famous art colony, they even hope to find a trace of Amálka because her memory book vaguely states that she lived there. They also visit Novszka, presently Croatian Novska, and Nagyvárad, today's Romanian Oradea, along with many other towns and places. 
Pereszlényi-Pintér, Mártha. "Fischer, Linda. 2014. The Memory Book - One Woman's Self-Discovery in the Mist of the Austro-Hungarian Monarchy. New York: Minted Prose. 326 pp." Hungarian Cultural Studies. e-Journal of the American Hungarian Educators Association, Volume 10 (2017) DOI: 10.5195/ahea.2017.307

The couple's trip is facilitated and enriched by the help and guidance of Richard Bogdán, a native Hungarian and expert in Hungarian travel, and is shared with the author's AsianAmerican friend Min. In some of Hungary's neighboring countries Fischer can witness the lingering ethnic tensions. For instance, in Romania, their Romanian guide, a man of Hungarian descent whom they call Mr. D., loads them up with historical details of Transylvania's remote history. This Mr. D. speaks Hungarian to their guide Richard Bogdán, who then translates him to English. Apparently, Mr. D.'s use of Hungarian in this Romanian-speaking environment causes some unrest, and once an incident in a Romanian restaurant leaves him visibly shaken, yet he would not disclose to his audience of American tourists what it was all about.

A careful reading of the memory book teaches us that Amálka most probably lived in or near Szolnok, and that her mother was from Novszka/Novska. Amálka's memory book is replete with reflections and pearls of wisdom, with most of the quotations and aphorisms in it attributed, including dates, to their respective writers. Amálka's watercolor drawings, as well as a few by other artists of various degrees of talent, fill several pages. In addition, many of the aphorisms, poems, and greetings and blessings of all sorts are decorated with colorful flora and fauna in their margins, thus making each page carry its own motif. In 1906, Amálka's mother writes the first entry, intertwined by twigs freshly sprouting. Amálka's memory book describes, among other events, a wedding of a couple by the names of Valéria and Józsi, dated May 11, 1907; as well as apple picking in Nagyvárad/Oradea on October 8, 1907. Several entries may have been penned by Amálka's suitors or potential suitors, while other entries and signatures are by her friends and relatives.

In November 1918, following World War I, an armistice was signed between AustriaHungary and The Allies. The end of the war marked the end of Hungary's Imperial existence and the loss of some two thirds of its territories and of its population, to neighboring countries. Accordingly, the memory book's entries of 1918 advise about handling loss and retaining hope. Fischer makes a particular comment on an entry which features a watercolor of a solitary fisherman in a flat-bottom boat that seems to be sailing on the Tisza River. Responding to this entry, Fischer writes that for Amálka and her people, it “... had to be wrenching to see Hungarians and Romanians battling on the gentle Tisza River in the summer of 1919. All manners of privation, from lack of food and supplies, and general barbarity ruled. There were not even enough gravediggers" (55).

Fischer engaged graphologists to attempt to determine Amálka's age during the time she was writing her memory book, and based on their analyses she surmises that when the book cuts off in 1919 Amálka may have been about eighteen years old. This information leaves us with several open questions: Did Amálka elect to stop or end her memory book, possibly because she felt too mature for it? Did she marry at that time? Or, possibly, considering the hard times around the end of the war, did she perish? Hungary in 1919 was a procession of tragedies so it may well be that the abrupt ending of Amálka's book could testify to the tragic fate that befell its author.

In addition to her journey following Amálka's memory book and world, Fischer displays her own reconnaissance with the Hungarian language and the bafflements she faced while trying to achieve even a modest command of it. She is to be commended for attempting to learn this foreign language as an adult, with a private tutor. By lesson number nine, she feels overwhelmed yet unwilling to quit, and she notes that she did better than composer Franz Liszt, who purportedly gave up on learning Hungarian after only five lessons. The word that allegedly killed it for Liszt was tántoríthatatlanság, which means "unshakability." But Fischer toils on to grasp 
Pereszlényi-Pintér, Mártha. "Fischer, Linda. 2014. The Memory Book - One Woman's Self-Discovery in the Mist of the Austro-Hungarian Monarchy. New York: Minted Prose. 326 pp." Hungarian Cultural Studies. e-Journal of the American Hungarian Educators Association, Volume 10 (2017) DOI: 10.5195/ahea.2017.307

the rules of word order, the agglutinative nature of the language with its suffixes, prefixes and vowel harmony, and to master intonation and pronunciation by citing words such as kimüvelhetetlenségeskedéseitekre, meaning "to counteract your uneducatedness..."

Are you looking for a travelogue book? Then pick up an assiduously researched volume by Rick Steves (American travel writer, author, activist and television personality). Do you insist on a history book written in academic style? Then look for it in an academic library - this book is not for you. Do you want to check the author's primary sources? Pick up John Paget's History of Hungary and Transylvania (1839), whom the author quotes extensively. (Paget was an English agriculturalist who married a Transylvanian Hungarian baroness and died in 1892 in Kolozsvár, now known as Cluj in Romania.) Do you want a light read and romantic fiction in the genre of "an American's experience abroad"? Then get yourself a copy of Elizabeth Gilbert's Eat Pray Love (2007), but note that some reviewers have unflatteringly labeled it as a selfindulgent perspective about the writer's self-discovery. The latter bears no resemblance to Fischer's The Memory Book which is much more focused on the rich culture and history that the writer explored.

Amálka's memory book inspired the author to help the girl who wrote it live on and spread a message of love and hope in our time. In Amálka's own memory book, her story begins and ends not with her birth and death, but rather with her life between in 1906 and 1919. Did Linda Fischer finally discover this girl's true identity and those of her family and friends? Ah for the answer to that, dear reader, you too will have to voyage through time, space, and memory, and read the book for yourself all the way to the grand finale. 